\title{
Monetary Policy Actions and Agricultural Sector Outcomes: Empirical Evidence from South Africa
}

\author{
Brian Muroyiwa \\ Department of Agricultural Economics and Rural Extension, University of Fort Har \\ Email: bmuroyiwa@gmail.com, \\ Innocent Sitima \\ Department of Economics University of Fort Hare \\ Email: innositima@gmail.com \\ Kin Sibanda \\ Department of Economics University of Fort Hare \\ Email:keith08.kin@gmail.com \\ Abbyssinia Mushunje \\ Department of Agricultural Economics and Extension University of Fort Hare \\ Email: amushunje@ufh.ac.za
}

Doi:10.5901/mjss.2014.v5n1p613

\section{Abstract}

This study looks at the impact of monetary policy on South African agriculture, making use of the linkages that exist between interest rates, the macroeconomic environment and the agricultural sector. Utilising yearly data from 1970 to 2011, this study empirically investigates the impact of monetary policy on agricultural gross domestic product in South Africa using Vector Error Correction Model (VECM). The study finds that inflationary shocks and the money market rate have an enormous negative impact on the performance of the Agricultural GDP whilst the manufacturing index and the stock market help to improve the agricultural GDP. A unit increase in money market rate results in a decrease in the Agricultural GDP by approximately 0.021 percentage points. The study concludes that it is imperative for South Africa's monetary policy authorities' and agricultural sector policy makers as well participants to consider carefully the interaction between the macroeconomic environment, agricultural sector and stock prices.

Keywords: Monetary Policy, VECM, Agricultural GDP

\section{Introduction}

In South Africa agriculture is a broad sector which comprises and involves fishery, forestry, livestock and crop production as well the processing and marketing of that agricultural output. It plays a crucial role in the development process and well-being of humanity and it is classified a strategic sector of the economy. The primary agriculture sector contributes $3 \%$ to the Gross Domestic Product (GDP) of South Africa and employs 7\% in formal employment (South African Government Information, 2012). Furthermore agriculture has strong linkages in the economy so that the agro-industrial sector contributes 12\% to GDP (South African Government Information, 2012). Kargbo (2007) asserts that 48\% of agricultural sector spending is on buying farm inputs whilst $66-71 \%$ of agricultural output is used as intermediate inputs in the industrial sector. These statistics are clear testimony to the fact that the role agriculture plays in the South African economy can never be over-emphasised. Agriculture not only has various interrelationships with other sectors of the economy but more importantly it shares a distinct relationship with the monetary sector of the economy. Due to its nation building characteristics, as well as backward and forward linkages agriculture continues to be a target of government policies over time. Monetary policy conduct influences agricultural sector activities therefore a clear understanding of monetary policy practice in South Africa is crucial in order to link it with agriculture. 
Monetary policy is the starting point of monetary policy transmission mechanism (Monetary Policy Committee, 1999). Although there are arguments that the interest rate is market determined in actual sense it is influenced by the Central Bank through the Monetary Policy Committee (MPC). There are meetings at given intervals where the MPC meets to decide the fate of interest rates and this is where a decision on the repo rate is made. The excess units meet deficit units in the money market through a financial intermediary and they exchange short term financial claims and assets. Farmers, agro-processors as well as other agricultural sector stakeholders are participants in the money market since farming as any other business requires funding.

Farm sector agents participate in the money market when they borrow money to secure machinery, inputs and working capital. Department of Agriculture Forestry and Fisheries (2010) states that farm debt has been on the increase since a farmer will borrow to finance acquisition of a machine regardless of how low or high interest rates are. Nevertheless monetary conditions would have a lot do with the availability of credit which ultimately influences agricultural sector performance. Therefore the SARB is at the centre of influencing money market rates through the repo rate. The SARB regards its main objective in the South African economy as the achievement and maintenance of price stability in the interest of balanced as well as sustainable economic growth (SARB, 2012). These goals are pursued through some conventional instruments which are at the disposal of the Central Bank namely interest rates, open market operations, reserve requirements, moral suasion, lending, direct credit control and prudential guidelines. The SARB strives to modify economic behaviour in ways that will help to achieve their ultimate objectives.

Muroyiwa (2011) asserts that when economic agents borrow it is largely because they want to finance acquisition of an asset. Borrowing may be to finance the purchase of a house, car, combine harvester, an industrial machine, plant and equipment. The essence of this argument is that borrowing finances productive activity. Productivity in the farm sector and non- farm sector is attributed to growth over time in credit extended. Farmers' incentive to produce is related to ability to successfully market and sell their produce. Growth in credit extension is linked to growth in demand for goods and services. The growth of credit extension is also the growth in M3 that is money supply. Growth in money supply is not inflationary as long as the growth in money is attached to growth of national output. The increased demand leads to multiplication in productive activities to satisfy the demand. When aggregate demand increases firms do well, farmers prosper as their income increases; profits of companies soar. Investors are always on the lookout for companies that are performing well. Performance is measured according to the profitability of the company. If a company is doing well in the market investors would jostle for its shares. Investors stampede for shares of blue chip companies; this just as well increases the price of the share due to demand and supply dynamics.

An attempt here is made to investigate and report on the impact of monetary policy shocks on interest rates, stock prices, inflation, exchange rates and money market rates. The impact of the monetary policy shock eventually find its way into the agricultural sector. The primary objective of this study therefore is to examine the linkages between monetary policy, stock prices, macroeconomy and the agricultural sector. The rest of the paper is organised as follows Section 2 presents the overview of monetary policy practice in South Africa, Section 3 discusses the theoretical and empirical literature on monetary policy and agricultural sector, Section 4 discusses the VECM model (data and econometric methodology) used in this study; Section 5 presents the empirical results and the main findings of the study while the conclusions and policy inferences are discussed in Section 6.

\section{Overview of Monetary Policy Practice In South Africa}

The South African monetary policy has been conducted under three broad monetary regimes in the past five decades which are the liquid asset ratio- based system, cash reserves based system and flexible money supply targeting (Aron and Muellbauer, 2007). Monetary authorities utilised the liquid asset ratio- based system in the 1960's with quantitative controls on interest rates and credit. This policy was in use only until the early 1980's when a range of monetary policy reforms were enacted towards a cash reserves based system as a result of recommendations made by the de Cock Commission Reports of 1978. Cash reserve based system was adopted thereafter. Gidlow (1995) claims that the cash reserve based system was in full operation by mid-1985 subsequent to technical changes on asset requirements and a redefinition of the role of the discount rate.

Money supply targeting emphasised the role of the central bank discount rate in influencing market interest rates. The usefulness of monetary targeting was diminished by the extensive financial liberalisation beginning in the 1980's (Aron and Muellbauer, 2007). It became increasingly difficult to set and meet the monetary targets due to a more open capital account from 1995 (Aron and Muellbauer, 2007). Money supply targeting was replaced by money supply guidelines in 1990. In February of 2000 inflation targeting was formally introduced in South Africa. Until after the adoption 
of the inflation targeting the only revision on the focus of monetary policy was monetary targets were supplemented by an eclectic set of indicators including exchange rates, asset prices, wage settlements and the balance of payments (Aron and Muellbauer, 2007). Monetary regulators formally adopted the inflation targeting policy on 6 April 2000.

In order to meet the objectives of this study the interest rate channel of monetary policy will be utilised. Much has been documented in financial and monetary economics literature about the interest rate channel of monetary policy (Mishkin,2007). It is the most popular instrument for central banks, nevertheless isolation of this monetary policy transmission mechanism tool is not meant to supersede it over other monetary policy transmission mechanisms. The level of money supply is influenced by interest rates and determines the credit extension in the economy. Money market rates are a barometer for the affinity of financial institutions in extending credit. Expansionary monetary policy increases the level of credit extension in the economy while contractionary monetary policy reduces credit extension. Nevertheless the role of credit extension in most economies has been largely underemphasised yet credit extension is a driver of economic activity. Purcell (1983) qualifies this statement asserting that it is the role of government to provide a sound credit system to foster economic development. He further states that credit is essential to advancing productivity in primary agriculture and post farm sectors.

\section{Theoretical and Empirical Literature}

A broad sum of literature has attempted to discuss the linkages between agriculture and monetary policy with an enormous body of knowledge on the subject mainly found in the United States. Early contributions are attributed to (Schuh, 1974; Shei, 1978; Tweten, 1980; Barnett et al, 1981; Chambers and Just, 1982; Starleaf, 1982; Bessler, 1984; Chambers, 1984; Devadoss et al, 1985; Orden, 1986; Barbhart, 1989; Orden and Fackler, 1989). These researchers focused on the impact of monetary policies on the aggregate farm sector variables as well as the impact of macroeconomic factors on the agricultural sector. Their findings provide sufficient evidence of significant linkages between monetary policy and farm sector; as well agricultural sector and macroeconomic variables. It is concluded that an expansionary monetary policy favours the agricultural sector, which results in an increase in agricultural output prices, exports and incomes. In a practical sense changes in macroeconomic variables result in changes in farm output prices, exports and income. The central bank has tools such as the repo rate (interest rate) to influence changes in macroeconomic variables.

Most of the related studies done in South Africa have used annual data as well as different set of methodologies. Dushmanitch and Darroch (1990) used annual data from (1967 -87) to estimate equations representing livestock, field crop, horticultural and manufacturing sectors, as well as the foreign exchange and money markets. They utilised a general equilibrium simultaneous equation model to analyse the impact of monetary policy on agriculture. The results of their study highlight that monetary policy has a significant impact on South African agriculture. Kargbo (2007) arrives at a similar conclusion using a vector error correction model and utilising annual data in order to investigate the dynamic effects of money supply, exchange rates and other macroeconomic variables on the agricultural sector in South Africa.

Distinct from other studies reviewed for South Africa (Asfaha and Jooste, 2007) use monthly series data to investigate the effect of monetary changes on relative agricultural prices. However similar to Kargbo (2007), Asfaha and Jooste (2007) use the Johansen approach for cointegration and vector error correction model to investigate the short run and long run effects of monetary changes on relative agricultural prices. Their findings confirm a long run relationship between South African agricultural and industrial prices, the money supply and exchange rate. They conclude that the agricultural sector is affected by changes in macroeconomic variables. The central government has in hand two tools to influence economic activity (fiscal and monetary policy), although most of the changes in the economy are transmitted through monetary policy.

Interest rates are the major policy instrument for most central banks including the South Africa Reserve Bank. Earlier studies on the relationship between interest rates and the farm sector postulate that expansionary monetary policy is favourable for agricultural sector productivity (Starleaf, 1982, Devadoss et al, 1985). Lower interests relax borrowing conditions which is an incentive for farmers to secure loans and increase their productivity. Contractionary monetary policy has an opposite effect though it reduces money supply and tames the rate of inflation. Changes in monetary policy will feed into the livestock supply, crop supply, stock demand, input supply and demand decisions.

\section{Methodology}

Annual data from 1970-2011 is utilised to estimate a Vector Error Correction model (VECM). The VECM is employed to 
test the long and short run effects of monetary policy on agricultural GDP in South Africa. Diagnostic tests are also carried out to test for autocorrelation, heteroscedasticity and normality. Data was obtained from the South African Reserve Bank (SARB), Quantec easy data and Statistics South Africa.

Preliminarily, data is tested for unit root problem using the Augmented Dickey Fuller and Phillips-Perron tests. According to Newbold and Granger (1974) the effects of non stationarity includes spurious regression, high $\mathrm{R}^{2}$ and low Durbin-Watson (dw) statistic. This therefore, prompted the need to test for stationarity or otherwise of the time series. The Johansen cointegration analysis is used to test for cointegration. The maximum eigenvalue and trace statistics were generated to determine the number of cointegration vectors in the model. Impulse response analysis is used to trace out the responsiveness of the dependent variable in the VAR to shocks to each of the other variables. Variance decomposition analysis as according to (Brooks, 2008) was employed to provide the proportion of movements in the dependent variables that are due to its own shocks, against shocks to other variables.

\subsection{Specification of the Model}

The main aim of the study is to examine the impact of monetary policy on agricultural output in South Africa. In order to achieve this, the study benefits a lot from the work of (Okidim and Albert, 2012). The study shall adopt and modify the (Okidim and Albert, 2012) model of the analysis of the effects of monetary and fiscal policy indicators on agricultural output (Cereal) (1990-2000). Their model was formally specified as below:

$$
Y=F\left(X_{1}+X_{2}+X_{3}+X_{4}+X_{5}\right)+\mu
$$

Where:

$\mathrm{Y}=$ Agricultural Output (Cereal); $\mathrm{X}_{1}=$ Inflation; $\mathrm{X}_{2}=$ Budget Allocation; $\mathrm{X}_{3}=$ Savings; $\mathrm{X}_{4}=$ Monetary Supply; $\mathrm{X}_{5}=$ Interest Rates and $\mu=$ Error Term.

For the purposes of this study the Budget allocation, Savings and Monetary supply from the above model were replaced by Manufacturing index, Real effective exchange rate and Share index. In natural logarithms form our model takes the form:

$L N A G R G D P=\beta_{0}+\beta_{1} L N C P I+\beta_{2} L N N M I+\beta_{3} L N N E E R+\beta_{4} L N S I I C+\beta_{5} L N M M R+\mu_{\ldots \ldots .2}$

Where:

AGRGDP is the Agricultural Gross Domestic Product; CPI is the Consumer Price Index (Inflation); MI is the Manufacturing Index; MMR is the Money Market Rate; NEER is the Nominal Effective Exchange Rates and SIIC represents Johannesburg All Share Index.

\section{Main Findings}

To avoid spurious results and "nonsensical" regression the study undertakes a stationarity test using the Augmented Dickey Fuller (ADF) and the Phillip Peron (PP) test. The results are given in Table 1 below:

Table 1: Unit root tests

\begin{tabular}{|c|c|c|c|c|c|c|}
\hline & LNAGRGDP & LNCPI & LNMI & LNNEER & LNSIIC & LNMMR \\
\hline \multicolumn{7}{|l|}{ ADF } \\
\hline Level & -1.811611 & $-2.67209^{*}$ & $-2.4616^{\star \star}$ & -0.857 & -0.470 & $-2.9335^{\star \star}$ \\
\hline First Difference & $-6.14346^{\star \star \star}$ & - & $-5.249^{\star \star \star}$ & $-4.854^{\star \star \star}$ & $-5.920^{\star \star \star}$ & $-5.598^{\star \star \star}$ \\
\hline \multicolumn{7}{|l|}{ PP } \\
\hline Level & $-6.06592^{\star \star \star}$ & $-2.2089^{*}$ & $-2.8227^{\star \star}$ & -0.857 & -0.4612 & $-2.1186^{\star \star}$ \\
\hline First Difference & - & - & $-5.191^{\star \star \star}$ & $-4.777^{\star \star \star}$ & $-5.991^{\star \star \star \star ~}$ & $-5.236^{\star \star \star}$ \\
\hline
\end{tabular}

The results show that all variables are stationary at $5 \%$ and we are able to adopt a dynamic time series model.

Literature offers various lag length selection criterias utilised to obtain optimal lag length. Table 2 below shows that both the SIC and AIC selected 1 and 3 lags respectively for the VAR. The information criteria approach has therefore produced incompatible results and no conclusion can be arrived at, using these approaches only. Therefore the lag length for the VAR chosen is informed by LR and HQ criteria which suggest a more optimal lag length, therefore the study uses a lag structure of 2 . 
Table 2: Lag structure selection criteria

\section{Notes:}

\begin{tabular}{|c|c|c|c|c|c|c|}
\hline Lag & LogL & LR & FPE & AIC & SIC & HQ \\
\hline 0 & -54.05220 & NA & $8.76 \mathrm{e}-07$ & 3.079600 & 3.335532 & 3.171426 \\
\hline 1 & 201.4435 & 419.2749 & $1.16 \mathrm{e}-11$ & -8.176588 & $-6.385060^{\star}$ & -7.533803 \\
\hline 2 & 264.4105 & $83.95602^{\star}$ & $3.33 \mathrm{e}-12$ & -9.559512 & -6.232389 & $-8.365769^{\star}$ \\
\hline 3 & 310.4387 & 47.20842 & $2.92 \mathrm{e}-12^{\star}$ & $-10.07378^{*}$ & -5.211061 & -8.329078 \\
\hline
\end{tabular}

* indicates lag order selected by the criterion

LR: sequential modified LR test statistic (each test at $5 \%$ level)

FPE: Final prediction error

AIC: Akaike information criterion

SIC: Schwarz information criterion

HQ: Hannan-Quinn information criterion

We performed a co-integration analysis to check for any long run relationship among the variables of interest. We adopted both the Trace test and the Maximum Eigen Value test to test for any long run association. The results from these tests are shown below as Table 3 and 4.

Table 3: Co integration Rank test (Trace) Results

\begin{tabular}{|l|c|c|c|c|}
\hline Hypothesized & & Trace & 0.05 & \\
\hline No. of CE(s) & Eigen Value & Statistic & Critical Value & Prob. $^{* *}$ \\
\hline None * & 0.787068 & 154.5897 & 95.75366 & 0.0000 \\
\hline At most * $^{*}$ & 0.619096 & 94.26523 & 69.81889 & 0.0002 \\
\hline At most ${ }^{*}$ & 0.473926 & 56.62213 & 47.85613 & 0.0061 \\
\hline At most $3^{*}$ & 0.353407 & 31.57193 & 29.79707 & 0.0309 \\
\hline At most 4 & 0.212831 & 14.56645 & 15.49471 & 0.0686 \\
\hline At most ${ }^{*}$ & 0.125573 & 5.233253 & 3.841466 & 0.0222 \\
\hline
\end{tabular}

The Trace test suggests that there are at most 4 cointegrating equations with a long run association at $5 \%$ confidence interval. The maximum eigenvalue test suggested that there are at most 2 cointegration equations in the model at $5 \%$ confidence interval as revealed by table 4 below.

Table 4: Co integration Rank test (Eigen Value) Results

\begin{tabular}{|l|c|c|c|c|}
\hline \multicolumn{1}{|c|}{ Hypothesized } & & Max-Eigen & 0.05 & \\
\hline No. of CE(s) & Eigen Value & Statistic & Critical Value & Prob.** \\
\hline None * & 0.787068 & 60.32450 & 40.07757 & 0.0001 \\
\hline At most 1 & 0.619096 & 37.64310 & 33.87687 & 0.0169 \\
\hline At most 2 & 0.473926 & 25.05020 & 27.58434 & 0.1020 \\
\hline At most 3 & 0.353407 & 17.00548 & 21.13162 & 0.1717 \\
\hline At most 4 & 0.212831 & 9.333197 & 14.26460 & 0.2595 \\
\hline At most 5 & 0.125573 & 5.233253 & 3.841466 & 0.0222 \\
\hline
\end{tabular}

The VECM model allows the model to capture both the long run and the short run dynamics in the model. The long run results and equation of the model are given below as Table 5 .

Table 5: Long run co- integration equation results

\begin{tabular}{|l|c|c|c|}
\hline \multicolumn{1}{|c|}{ Variable } & Coefficient & Standard error & t- statistic \\
\hline Constant & -7.481207 & - & - \\
\hline LNAGRGDP & 1.000000 & - & - \\
\hline LNCPI & -0.621735 & 0.06635 & -9.37015 \\
\hline LNMI & -0.484273 & 0.09501 & -5.09684 \\
\hline
\end{tabular}




\begin{tabular}{|l|c|c|c|}
\hline LNNEER & 0.431512 & 0.05094 & 8.47043 \\
\hline LNSIIC & -0.076186 & 0.02870 & -2.65469 \\
\hline LNMMR & 0.021887 & 0.00255 & 8.59024 \\
\hline
\end{tabular}

$A G R G D P=-7.481207-0.6217 C P I-0.4842 M I+0.4315 N E E R-0.0761 S I I C+0.02188 M M R$

The model suggests that in the long run, $\mathrm{CPI}, \mathrm{MI}$ and SIIC have a negative impact on Agricultural GDP (AGRGDP) while both NEER and MMR have a positive relationship with AGRGDP. A change in CPI has more impact on Agricultural GDP (AGRGDP) than any other determinant in the model. The results suggest that a unit change in CPI results in a 0.621 percentage point decrease in the Agricultural GDP, this could have been caused by the fact that as the AGRGDP is more responsive to a change in the $\mathrm{CPI}$ and inflationary pressures. A unit change in the manufacturing index and the stock market results in a decrease in AGRGDP by approximately 0.484 and 0.076 percentage points respectively. A stronger rand exchange rate coupled with a higher money market rate results in a positive increase in the agricultural GDP in the long run.

In the long run a persistent deterioration in the CPI has the major impact on agricultural GDP since the decline in the price level will render agribusiness unsustainable. In addition to the long run results, table 6 below shows the short run dynamics.

Table 6: Short run co- integration equation

\begin{tabular}{|l|c|c|c|}
\hline \multicolumn{1}{|c|}{ Variable } & Coefficient & Standard Error & t- statistic \\
\hline D(LNAGRGDP(-2)) & -0.482580 & 0.14959 & -3.22601 \\
\hline D(LNMI(-1)) & 1.442338 & 0.41204 & 3.50047 \\
\hline D(LNSIIC(-2)) & 0.154118 & 0.08199 & 1.87965 \\
\hline
\end{tabular}

The short run model shows that only AGRGDP, MI and SIIC tend to have any statistical significance to the AGRGDP. The results have shown that agricultural GDP affect itself negatively in the second lag suggesting that policies targeting the AGRGDP will have a negative effect in the short run. Therefore SARB is discouraged from adapting policies directly targeted on the agricultural sector in the short run as this hurts the sector. However, MI and SIIC have a positive effect on AGRGDP in the short run suggesting that a manipulation of the money market rate and stock market tend to cause a positive effect on AGRGDP in the short run. Moreover policies that affect the stock market is from previous two years.

We then conducted some diagnostic checks to check for some fundamental aspects of the model in terms of stability, normality and any signs of autocorrelation as these could result in some detrimental effects on the model and compromise the efficiency of the model itself. Table 7 below shows some of the diagnostics checked in the model for this paper.

Table 7: Diagnostic checks

\begin{tabular}{|l|l|c|c|}
\hline \multicolumn{1}{|c|}{ Test } & \multicolumn{1}{|c|}{ Null Hypothesis } & t- statistic & Probability \\
\hline Langrage Multiplier LM) & No serial correlation & 30.07204 & 0.7458 \\
\hline White CH-sq & No conditional heteroscadisticity & 544.4718 & 0.5104 \\
\hline Jarque- Bera & There is no Normal distribution & 6.657735 & 0.8794 \\
\hline
\end{tabular}

The diagnostic results show that the null hypothesis is rejected for all tests thereby concluding that there is no serial correlation and no heteroscadasticity. We can safely conclude that the above results show that the data is normally distributed.

Impulse response and a variance decomposition are also conducted to check how the model accommodates any shocks or deviation from the exogenous variables. Figure 1 given in the Appendix shows the impulse response of AGRGDP to its determinants, the results show that the model responds well to all shocks with exception of CPI which seems to divert away from the shock. Table 8 shows the variance decomposition for 10 years and the results have shown that all shocks in the first year can be explained by itself and in the $6^{\text {th }}$ year only approximately $68 \%$ of the shocks are explained by AGRGDP while MMR, MI and SIIC explain in total $27 \%$ with MMR explaining more of these shocks 
Table 8: Variance Decomposition of LNAGRGDP

\begin{tabular}{|c|c|c|c|c|c|c|c|}
\hline Period & S.E & LNAGRGDP & LNCPI & LNMI & LNNEER & LNSIIC & LNMMR \\
\hline 1 & 0.07830 & 100.0000 & 0.00000 & 0.00000 & 0.000000 & 0.000000 & 0.000000 \\
\hline 2 & 0.13971 & 77.34391 & 4.12520 & 12.3950 & 0.553422 & 0.020942 & 5.561419 \\
\hline 3 & 0.19669 & 63.54303 & 5.44851 & 9.20352 & 0.315174 & 7.525412 & 13.96435 \\
\hline 4 & 0.23146 & 64.29477 & 4.02100 & 6.80034 & 0.249665 & 6.982057 & 17.65216 \\
\hline 5 & 0.24923 & 66.55251 & 3.56719 & 6.34634 & 0.296853 & 6.426194 & 16.81090 \\
\hline 6 & 0.26784 & 68.10051 & 3.09046 & 6.81967 & 0.342702 & 6.207284 & 15.43938 \\
\hline 7 & 0.28739 & 70.11809 & 2.70709 & 6.79467 & 0.384475 & 6.031344 & 13.96433 \\
\hline 8 & 0.30893 & 71.30055 & 2.34465 & 7.41052 & 0.335546 & 5.633720 & 12.97501 \\
\hline 9 & 0.33281 & 71.23258 & 2.13282 & 8.10555 & 0.294293 & 5.595600 & 12.63915 \\
\hline 10 & 0.35680 & 71.63701 & 1.94061 & 8.07306 & 0.259200 & 5.597271 & 12.49284 \\
\hline
\end{tabular}

\section{Conclusions and Policy Inferences}

The primary objective of this study was to examine the linkages between monetary policy, stock prices, macroeconomy and the agricultural sector. This study empirically investigated the impact of the monetary policy actions on influencing the Agricultural sector outcomes using annual South African data from 1970- 2011. The study utilised the Vector Error Correction Model (VECM) to explore this relationship. The results of the study given in the preceding section have shown that $\mathrm{CPI}, \mathrm{NEER}$ and MR have the most impact on the agricultural sector therefore determining the Agricultural sector GDP.

We can conclude that the South African Reserve Bank (SARB) should exercise extreme caution when it seeks to influence the direction of the interest rates on the money market in the short run as this could result disastrous effect on the agricultural sector. However the increase of interest rates in the long run leads to low CPI which in turn affect the Agricultural GDP favourably. Given the enormous evidence of interdependence between monetary policy, macroeconomic variables, stock market and agriculture sector as concluded from this study, Asfaha and Jooste (2007) recommend that agricultural policy makers and monetary policy makers work closely together in designing and implementing monetary policy in South Africa. This paper reaches a similar conclusion stating that what happens in the agricultural sector has a lot to do with monetary policy conditions as well as macroeconomic environment. The changes made by monetary authorities find their way into the agricultural sector. The interest rate channel of monetary policy transmission mechanism affects borrowing conditions and various macroeconomic factors which ultimately affect the farm sector. Central Bank is recommended to periodically influence outcomes in the agricultural sector through easier monetary conditions. However SARB should not consider direct intervention into the agricultural sector as this will result in diversion from their primary goal of achieving price stability resulting in price instability worsening agricultural conditions.

\section{References:}

Aron, J. And Muellbauer, J.(2007 ). Review Of Monetary Policy In South Africa Since 1994. Journal of African Economies, 16, 705-744. Asfaha, T. A. and Jooste, A. (2007). The effect of monetary changes on relative agricultural prices. Agrekon, Vol 46, No 4.

Barbhart, S. W. 1989. The effect of macroeconomic announcements on commodity prices. American Journal of Agricultural Economics, Vol 71:389-403.

Barnett, R.C., Bessler, D. A. and Thompson, R. L. 1981. Agricultural Prices in the 1970s and the Quantity Theory of Money. Paper presented at AAEA annual meeting. Clemson University. Clemson, South Carolina.

Bessler, D. A. 1984. Relative prices and money: a vector autoregression on Brazilian data. American Journal of Agricultural Economics, Vol 65: 25-30.

Brooks, C. (2008). Introductory Econometrics for Finance. Cambridge: Cambridge University Press.

Chambers, R. G. 1984. Agricultural and financial market interdependence in the short run. American Journal of Agricultural Economics, Vol 66:12-24.

Chambers, R.C and Just, R. E. 1982. An investigation of the effect of monetary factors on US Agriculture. Journal of Monetary Economics 9:235-47.

De Kock G. 1978. Commission of Inquiry into the Monetary System and Monetary Policy in South Africa. Final Report (Pretoria: Government Printer).

Department of Agriculture Forestry and Fisheries (2010) Increasing farm debt amid decreasing interest rates. Economic Research Division. Directorate Economic Services. 
Devadoss. S., Meyers, W. H. and Starleaf, D. R. 1985. The Impacts of US monetary policies on the farm sector. Paper presented at AAEA annual meeting. lowa University. Ames, lowa.

Dushmanitch,V .Y. and Darroch, M. A. G. 1990. An economic analysis of the impacts of monetary policy on South African agriculture. Agrekon Vol 29 No 4 pp 269-283

Gidlow, R.M., 1995a. South African Reserve Bank Monetary Policies under Dr. T.W. de Jongh, 1967-80.

Kargbo, J. M. 2007. The effects of macroeconomic factors on South African agriculture. Applied Economics.39.2211-2230

Mishkin, F., 2007. The Economics of Money, Banking, and Financial Market. Pearson, Boston.

Monetary Policy Committee. 1999. The transmission mechanism of monetary policy. Bank of England. [online] Available: http://www.bankofengland.co.uk/publications/Documents/other/monetary/montrans.pdf [Accessed August 2013]

Muroyiwa (2011) Identifying the interdependence between South Africa's monetary policy and the stock market.[Online] Available: http://eprints.ru.ac.za/2100/1/MUROYIWA-MCom-TR11-33.pdf [Accessed June 2013]

Newbold, P., and Granger, C. (1974). Spurious Regression in Econometrics. Journal of Econometrics, 2.

Odin, D. 1986. Money and agriculture: the dynamics of money-financial market-agricultural trade linkages. Agricultural Economics Research, Vol 38(3): 14-28.

Odin, D. and Fackler, P. 1989. Identifying monetary impacts on agricultural prices in VAR models. American Journal of Agricultural Economics, Vol 71: 495-502.

Purcell, J. C. 1983. The impact of monetary policy on agriculture, agribusiness and related activities. Journal of Agribusiness

Schuh, G. E. 1974. The exchange rate and U.S agriculture. American Journal of Agricultural Economics, Vol 22: 278-289.

Shei. S. 1978. The exchange rate and United States Agricultural Product Markets: A General Equilibrium Approach. PhD. dissertation. Purdue University. West Lafayette, Indiana

South African Government Information. 2012. [Online] Available: http://www.info.gov.za/aboutsa/agriculture.htm Accessed JULY 2012

South African Reserve Bank, 2012. Quarterly bulletin. May 2012 Pretoria: SARB

Starleaf, D. R. 1982. Macroeconomic policies and their impact upon the farm sector. American Journal of Agricultural Economics 64:854-60.

Tweeten, L. G. 1980. Macroeconomics in Crisis: Agriculture in an underachieving economy. American Journal of Agricultural Economics, Vol 62: 853-865.

\section{Appendix}

Figure 1: Impulse response one S.D Innovations

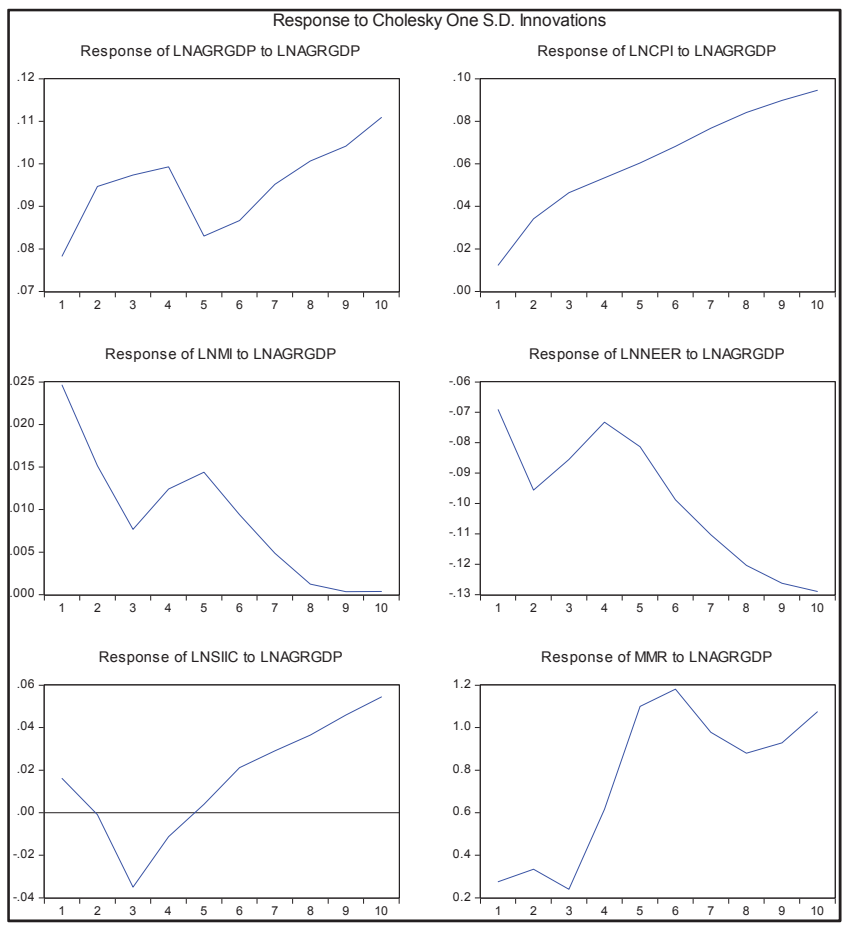

